\title{
The Importance of Exclusive Breast Milk and Complementary Foods in the Perspective of Islam
}

\author{
Sri Maryanti*, Meti Maspupah, Asrianty Mas'ud, \\ Sri Hartati \\ Program Studi Pendidikan Biologi \\ UIN Sunan Gunung Djati Bandung \\ Bandung, Indonesia \\ *sri.maryanti@uinsgd.ac.id
}

\author{
Dede Trie Kurniawan \\ Fakultas Keguruan dan Ilmu Pendidikan \\ UNSWAGATI \\ Cirebon, Indonesia \\ dhe3kurniawan@gmail.com
}

\begin{abstract}
Breastfeeding in the Islamic religion is a very importing. In the Qur'an mentioned, the period of breastfeeding in the teachings of Islam is two years. Word of Allah, Mothers shall suckle their children for two full years, that is for those who want perfect breastfeeding, (Surah al-Baqarah: 233). It is confirms that be a mother there is obligations for give intake best be breastfeeding for fruit his heart in range time particular. However thereby still many mothers who have difficulty. Breastfeeding her baby. Not only breast milk, breastfeeding food also need attention in the fulfillment of nutrition for growing children. Toddlers with less nutritional problems can cause disease, high risk of death compared to healthy children. One of the causes of low nutrient low in infants is the lack of knowledge of balanced nutrition held by mothers. Therefore, efforts to improve nutrition of one toddler with nutrition health education for mother under five. Activities have been carried out training exclusive breastfeeding and solids which meet the criteria of balanced nutrition at one of the community learning centers in Bandung. It can be seen from the activities that assisted Society more conscious will Importance breastfeeding difference formula with breast milk so if community assisted more priority to give milk to their babies. The community considers that the implementation of counseling is going well and according to their expectations, interesting and not saturated to be heard. Presenters was able to master and can explain in great detail extension materials and can answer all the questions raised by the participants.
\end{abstract}

Keywords-breast milk (ASI); complementary foods breast milk (MPASI); islamic perspective

\section{INTRODUCTION}

The importance of breastfeeding in the Islamic religion is mentioned in the Qur'an i.e., the period of breastfeeding in the teachings of Islam is two years. According to the Word of Allah SWT, Mothers should nurse their children for two full years, that is for those who want to perfect the breastfeeding (QS al-Baqarah: 233). This confirms that being a mother is an obligation to provide the best intake of breastfeeding for her baby within a certain span of time. However, there are still many mothers who have difficulty breastfeeding their babies. This is due partly because the baby's ability to suck milk is not perfect so that the whole process of breastfeeding is disrupted. In addition, in the current era where mothers start their career and work, the time to exclusively provide ASI is a big challenge and risk to be reckoned with since the start of the density of maternal activity in the current era and the short period of leave after childbirth. So that the fulfillment time of breastfeeding for two years become obstructed.

Breast milk (ASI) as a natural food is the best food a mother can give to her newborn child. In addition to the composition suitable for infant growth and development that changes according to the baby's needs at all times, breast milk also contains protective substances that can avoid infants from various infectious diseases. Breastfeeding also has a tremendous emotional effect that affects the mother's and children's inner relationships as well as the child's mental development. Likewise, there is a significant relationship between breastfeeding and birth spacing.

Exclusive breastfeeding, according to WHO, is breastfeeding only in infants up to 6 months of age without additional fluids or other foods. Breast milk can be given until the baby is 2 years old. Exclusive breastfeeding is encouraged by international guidelines based on scientific evidence on breastfeeding benefits for infants, mothers, families, and countries. Research conducted in Dhaka, in 1667 babies for 12 months said that exclusive breastfeeding can reduce the risk of death from acute respiratory infections and diarrhea.

This does not need to happen if the milk is given well and correctly, because breast milk alone can meet all the needs of infants until the baby is 6 months old. After six months until the age of 12 months, breast milk alone meets the needs of infants as much as $60-70 \%$ so that although the baby needs food other than breast milk, breast milk is also easier and faster to restore the mother's weight as before to get pregnant.

Not only breast milk, breastfeeding food (MPASI) also need attention in the fulfillment of nutrition for growing children. Toddlers with less nutritional problems can cause disease, high risk of death compared to healthy children. Under-five nutrition can also cause delay in motor development and low cognitive function. One of the causes of low nutrient low in infants is the lack of knowledge of balanced nutrition held by mothers. A housewife who daily used to prepare food for family members should have basic knowledge and skills about healthy and balanced nutrition 
menu. So that the food served is interesting for consumption and healthy to maintain the health status.

Lack of knowledge of nutrition and health of parents, especially mothers is one of the causes of nutritional deficiencies in infants. In Rural areas, food is heavily influenced by socio-economic and cultural circumstances. There is a taboo to eat in toddlers such as children not given fish because it can because intestinal worms, nuts are also not given because it can cause stomachache or bloating. Therefore, efforts to improve nutrition of one toddler with nutrition health education for mother under five. This right needs to be done to establish a positive behavior in terms of meeting nutritional needs as one of the important elements that support health in infants. In addition, it aims to influence the attitude, knowledge and behavior of the mother in the fulfillment of nutrition baby.

This paper focuses on the discussion of the importance of breast milk which should be given exclusively to newborns and how to determine balanced nutrition through mpasi (complementary foods of breast milk). This paper also describes the evaluation of ASI and MPASI material exposure activities at one of the community learning centers in Bandung as an evaluation of public education activities on maternal and child health.

\section{METHOD}

The method is done by collecting questionnaires of participants' responses after going through extension activities and workshops related to exclusive breastfeeding and balanced nutrition. In line with recent research results found that exclusive breastfeeding activities can help new mothers to restore their weight. Exclusive breastfeeding helps mothers lose weight that occurs during pregnancy faster than those who do not apply exclusive breastfeeding. The findings, published in The International Breastfeeding Journal, say, during the first 4 weeks after delivery, mothers who combine breast milk with formula milk lose weight. Nutritionally knowledgeable people will be more concerned with physiological needs than the psychic need for food. One of the indicators assessed for achievement in MDGs is the nutritional status of children under five. A housewife who daily used to prepare food for family members should have basic knowledge and skills about healthy and balanced nutrition menu. So that the food served is interesting to consume and healthy to maintain the health status [1]. Research from Frost et al in 2005 and Gyaltsen in 2007 revealed that lack of knowledge of nutrition and health of parents, especially mothers is one of the causes of malnutrition in infants [2, 3]. Mardiana (2005), Zuraida and Julita (2010) revealed that the number of mothers who knowledge of good nutrition will cause the nutritional status of children is also good [4, 5]. Means there is a correlation between mother's knowledge about nutrition with the development of children under five with good nutrition. A simple problem-solving framework can be illustrated in Figure 1 below.

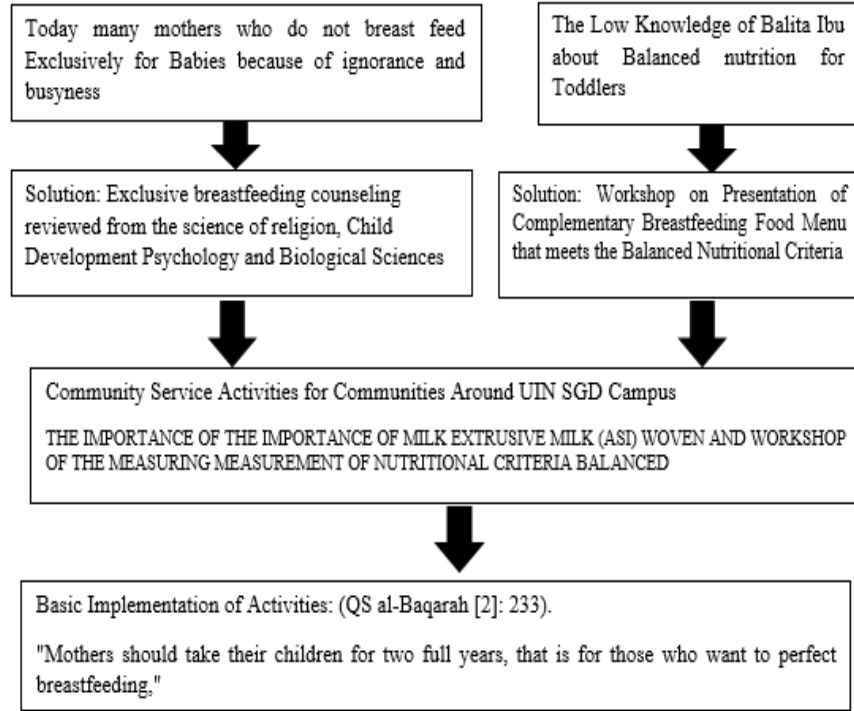

Fig. 1. Troubleshooting framework.

Counseling on the Importance of Exclusive Breast Milk (ASI) and Balanced Nutrition for Infants through Preparation MPASI is expected to help and provide new insights to prepare the balanced nutrition needed by the children it has. Stages of work plan in this activity is implied in the picture as follows:

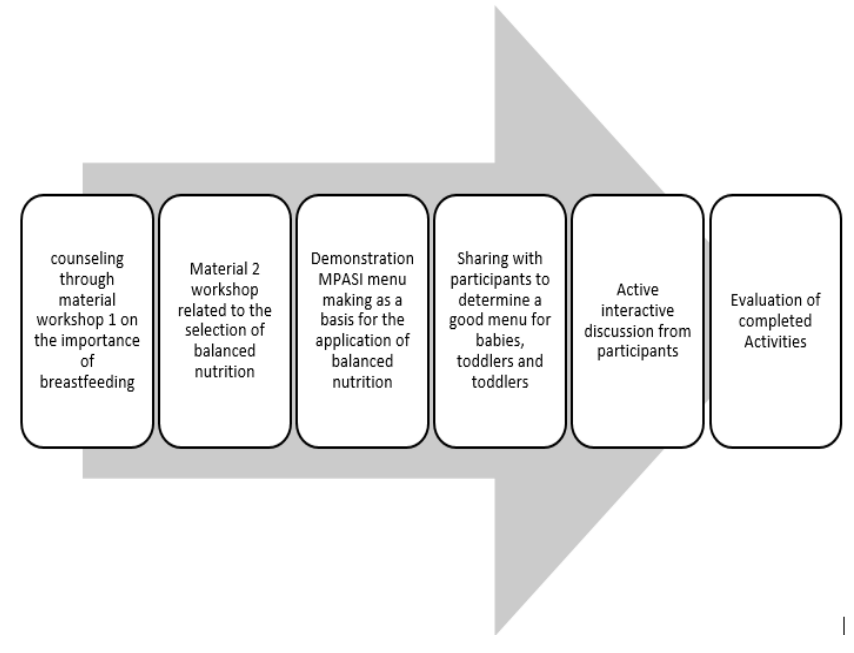

Fig. 2. Activity plan stage.

\section{A. Implementation}

This counseling activity is in the form of workshops conducted on the importance of breast milk which should be given to newborns exclusively and how to determine balanced nutrition through MPASI (maternal breast companion food) addressed to parents of PAUD Wijayakusumah and surrounding communities at the Learning Activity Center community (PKBM) Wijayakusumah with hope when giving direction and counseling to Participants in attendance then will become extension of hand to get information and knowledge can be soon spread to surrounding community. The target of this counseling participants is 30 for one PKBM 
Wijayakusumah area. In implementation this activity was accompanied by 5 members of devotees and 3 students HMPB (Biology Education Student Association)

This devotional activity focuses on the importance of breast milk that must be given to newborns exclusively and how to determine balanced nutrition through mpasi (complementary feeding) The target of this counseling is given to parents of PAUD Wijayakusumah and the surrounding community at the Learning Activity Center community (PKBM) Wijayakusumah The formulation of the problem of this extension program is to provide knowledge, insight and training to determine healthy menu with balanced nutrition needed by individuals including baby category, toddler, toddler in the surrounding area PKBM Wijayakusumah

The general aims of this counseling workshop on the importance of breast milk that should be given to newborns exclusively and how to determine the balanced nutrition through mpasi (complementary food breast milk) so that babies and toddlers are healthier and get a good intake so very support growth and development according to the expected age and provide knowledge about healthy lifestyle and direct practice to make mpasi as a form of fulfillment of balanced nutrition.

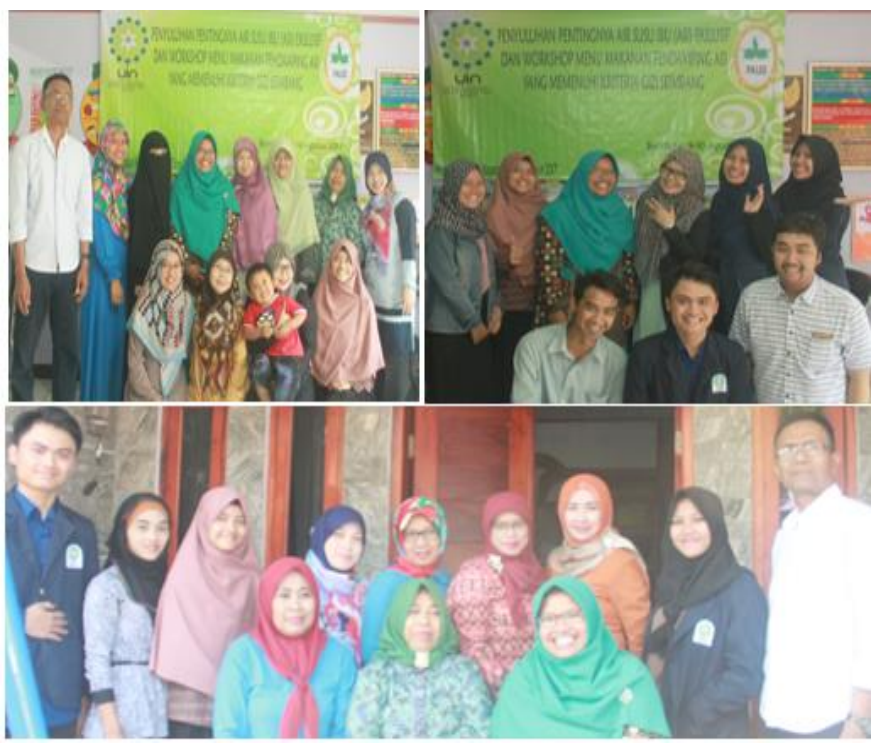

Fig. 3. Photo joint committee of $\mathrm{PkM}$ and management of PKBM Wijayakusumah.

The implementation of this counseling gained from the support of various parties. Especially LP2M UIN SGD Bandung who has provided letters of duty and administration equipment PKM so this program can be completed. The Biology Education Program Faculty of Tarbiyah and Teacher Training UIN SGD Bandung also supports the extension of the Importance of ASI and Balanced Nutrition, by providing news sheets of events and tools in the form of focus for the delivery of material.

This counseling was welcomed by various groups. The lecturers in Biology Education Program participated in this event carefully to the end. In addition, counseling was also attended by Biology Education Students and some representatives from the board of HMPB (Biology Education Student Association).

PKM program is considered very useful for the community. Moreover the location of the extension is located in the area around UIN Sunan Gunung Djati Bandung. Although the location is often held counseling both in the form of parenting and workshops, but only this time get counseling from UIN Sunan Gunung Djati Bandung. So get more enthusiasm from the community. Counseling is very interested by the mothers of PKBM, paud teachers, parents, even the supervisor PKBM Bandung City Education Department also took part in the event. In his speech, he said that this is the beginning of cooperation UIN Sunan Gunung Djati Bandung with early childhood and its PKBM in the hope will continue and can cooperate in various things especially for the progress of education and health.

\section{RESULTS AND DISCUSSION}

On Thursday, August 10, 2017 in PAUD Wijayakusumah has been busy as usual. Crowded by student participants and lecturers who prepare PKM program. Not only students, the head of PKBM Mr. Eddie Suwardi and his wife as well as treasurer PKBM happy to help us prepare the event eagerly awaited by the parents of PAUD Wijayakusumah students. Because the PAUD itself is often held workshops and parenting and new this time from UIN Sunan Gunung Djati Bandung provide counseling and workshops. Community service programs organized by LP2M are very easy to share knowledge and invite the public to realize their health, especially about MPASI and balanced nutrition that is expected to disseminate information to other communities.

Submission of the material followed by the second material is about balanced nutrition in infants. The need for food increases with age. In order to see the feedback from the participants then conducted data collection through a questionnaire. In figure 4 is the result of a questionnaire that has been done by the targeted participants as follows:

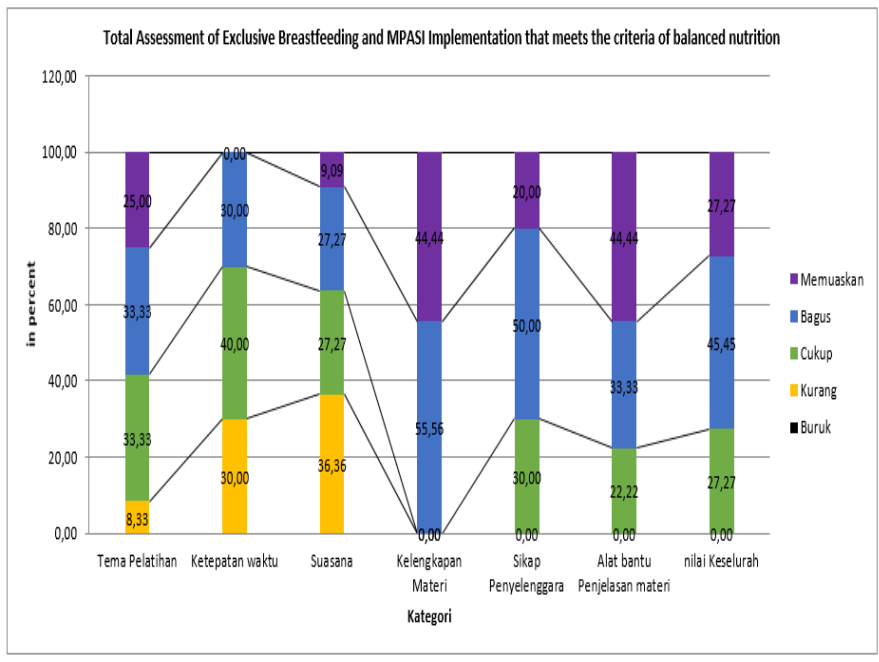

Fig. 4. Participant's response to activities. 
To assess the overall implementation of counseling, respondents were given a Lertert-scale questionnaire. Respondents assessed the theme presented in the extension activities as much as $33.33 \%$ enough and $33.33 \%$ good. With the theme "counseling the importance of exclusive breast milk (ASI) and workshop complementary breastfeeding food menu that meets the criteria of balanced nutrition," it is deemed able to answer the problems of mothers in the fulfillment of baby nutrition. $8.33 \%$ of respondents responded that the theme was inappropriate, it could happen because some mothers may already have enough knowledge about the theme.

When viewed from the timeliness, $40.00 \%$ of respondents agreed that the commencement of the event is quite timely as scheduled. The event is scheduled to start at 09.00 WIB. Some others as much as $30.00 \%$ he thinks less timely. The event ends up not in accordance with the specified time. This is because respondents are very enthusiastic when delivering extension materials so that trigger the speaker to do more improvisation and more detail in delivering it. This causes the event to last longer.

The atmosphere of counseling has been made to make the event conducive. In a room with the facility of shirt, in focus, sound system, and table with chair for speaker. From the results of the assessment respondents, $36.36 \%$ said less satisfied with the atmosphere of counseling. The venue for the event was less extensive to facilitate the respondents. Thus, seats are too close to each other and even some respondents do not get seats. This happens because the booming community that comes from both PKBM management, PAUD teachers, and guardians who want to follow the counseling. Because the place is limited, there are respondents who can not directly attend the event and can only listen to the speakers from the next room. As many as $27.27 \%$ said that the atmosphere was good enough and $27.27 \%$ considered the atmosphere of good counseling and $9.09 \%$ others considered the counseling given satisfactory, because it was supported by the media of delivering the material so that the atmosphere was more alive.

Two materials are presented by different speakers. Respondents gave responses of $55.56 \%$ of the material delivered by both good. Both speakers are experts in the field of material submitted. So it supports the delivery of material and can explain in detail and easily understood by the respondents. In addition, the use of video during the presentation of the material also makes respondents better understand and more interested to pay attention to the presentation more closely. $44.44 \%$ others rated the completeness of the material satisfactory. In addition to the slide show, the speaker provides a module to support the understanding of the respondent deeper and can be read back when returning home or in the necessary conditions.

The service and attitude of the receiver are satisfied as much as $20.00 \%, 50.00 \%$ good, and $30.00 \%$ enough. From the overall value, it can be said that the attitude of the organizers both student participants and extension workers succeeded in doing service to the respondents.

$44,44 \%$ stated the tool of delivery of material very satisfy, $33,33 \%$ good, and $22,22 \%$ enough. Submission of materials is assisted with the projector and in focus so that in addition to listening to the responder can also see what the speakers present from the slide shown. This makes respondents more able to absorb and understand the material. Hand out distributed to each respondent also makes it easier for respondents who get a seat behind or mothers who suffer from myopia and hypermetropy in order to read the writings submitted by the speaker.

Overall, $45.45 \%$ of the extension activities were considered good by the respondents. A total of $27.27 \%$ satisfactory and $27.27 \%$ is sufficient. From these results, it can be concluded that the implementation of counseling either in terms of timeliness, atmosphere, completeness material, service or organizational attitude, and tool delivery is said to be good.

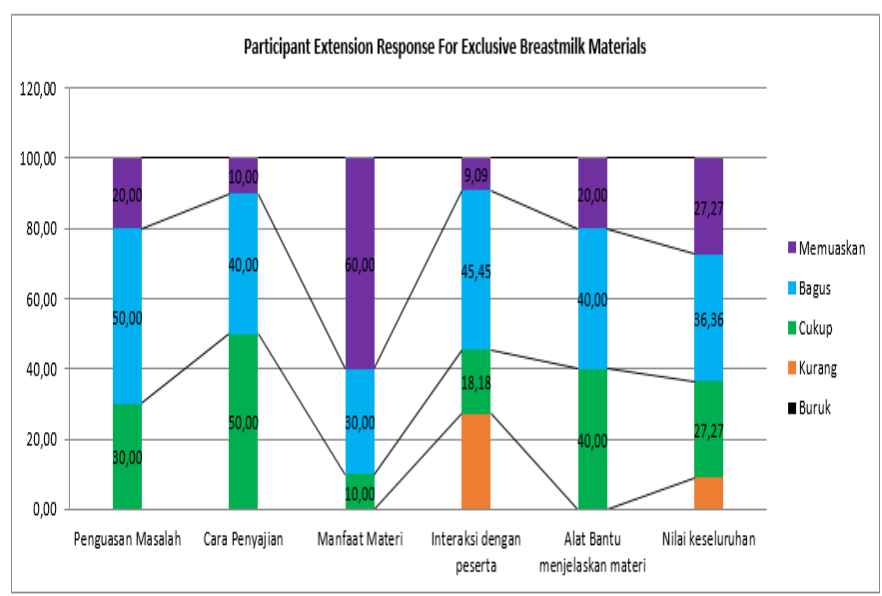

Fig. 5. Participant's response to exclusive asi materials.

Respondents were given a questionnaire to evaluate and provide feedback to exclusive breast feeder and MP-ASI for continuous improvement. Based on the participant's response, the speaker can master the problem by satisfying $20.00 \%$, $50.00 \%$ good, and $30.00 \%$ enough. The problem can be well conveyed by the speaker because it has educational background in accordance with the material presented.

The way the presentation of the material is delivered properly if you see the given response. $50.00 \%$ considered good enough by the respondents because the presentation of the material by the speaker delivered with a straightforward and easy to understand. $40.00 \%$ stated how good presentation and other $10.00 \%$ satisfactory. The material is presented with a language that is not too rigid that seems to flow.

In accordance with the background of the theme of the counseling, the material presented can be directly benefited by the respondents $30.00 \%$ good and quite good $10.00 \%$. $60.00 \%$ stated satisfactory material benefits because the knowledge gained from this counseling can be used as guidance for mothers with infant and also as guidance for improvement in the future.

The presenters not only explain the material at random with no regard to the participants' election. To create an interactive atmosphere, the speaker interacts with the participants in the middle of presenting the material by giving questions or responding to the participants' opinions regarding the material. 
A total of $45.45 \%$ of respondents rated the interaction of the presenters with good participants but another rating of $27.27 \%$ stated the lack of interaction with participants. This can be due to a limited time so that the speaker is more focused on pursuing the target for the material to be delivered entirely.

The tool to convey the material as a whole respondents give positive response that is $20.00 \%$ satisfactory, $40.00 \%$ good, and $40.00 \%$ pretty good. Submission of materials using media in focus, sound system, and handout so that the tool delivery is complete and very helpful respondents to understand what is presented by the speaker.

The delivery of exclusive ASI materials based on the above data is said to be successfully presented with a satisfactory amount of $27.27 \%, 36.36 \%$ good, and 27.27 quite good. The remaining $9.09 \%$ is less good as a result of the responses of respondents due to lack of interaction with participants.

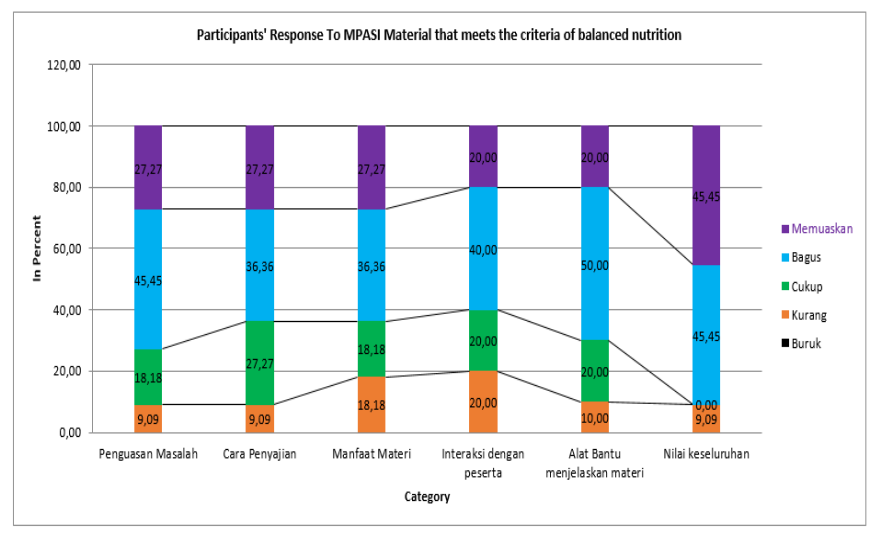

Fig. 6. Participant's response to exclusive asi materials.

Based on the diagram above, the response of counseling participants to MPASI that meet the criteria of balanced nutrition from several aspects is very diverse. The first aspect is the mastery of the material to the material presented by the $27.27 \%$ satisfactory, $45.45 \%$ good, and $18.18 \%$ good enough. From this value, the speaker has mastered the problem and the remaining $9.09 \%$ stated less problem because the delivery of material is accelerated so that there are some points that are not explained in detail given the limited time.

The way of presentation of MPASI material is not entirely good judged by the respondents. Compared with the way the presentation of exclusive breastfeeding ingredients all responded positively, however, the way of presentation of this material was considered less good by $9.09 \%$ by the respondents. This is because the time left is not much and the condition of participants who have started not conducive because it is close to prayer time dhuhur.

$27.27 \%$ of respondents said the benefits of MP-ASI material is very satisfactory, $36.36 \%$ good, and $27.27 \%$ good enough. Yet others as much as $18.18 \%$ feel less benefit from the material presented MPASI. Respondents assessed this possibility because the time of delivery of the material is noon so that the concentration has begun to decline.

As exclusive breastfeeding material, the presenters interact with the participants when delivering the MPASI material.
Only $20.00 \%$ of respondents assessed their interaction. Others as much as $40.00 \%$ respondents responding to the interaction of the presenters with the participants are good, $20.00 \%$ satisfactory, and $20.00 \%$ pretty good. It can be concluded that the interaction with the participants by the presenters is good and get a positive response.

The MPASI material delivery tool is the same as that used in exclusive ASI materials, however, the responses given by the respondents to the MPASI material delivery tool are varied i.e. $20.00 \%$ satisfactory, $50.00 \%$ good, and $20.00 \%$ quite good. $10.00 \%$ of the other respondents stated that the tool was lacking, in contrast to the exclusive breastfeeding material which responded well. This is due to the fact that the video does not appear to be related to MPASI material, unlike exclusive ASI material that many video displays. So the interest of respondents is reduced to this material.

It can be concluded from the various aspects that the overall content of MPASI satisfy as much as $45.45 \%, 45.45 \%$ good, and only $9.09 \%$ that rate less good. From the data, the counseling for MPASI material that meets the criteria of balanced nutrition get positive and good response by the extension participants.

In general, the assisted communities already know what it is. Exclusive breastfeeding. However, the understanding of exclusive breastfeeding is understood differently. Some answer exclusive breastfeeding is a natural food for babies up to age 2 years. In the balanced nutrition guide book published by the Ministry of Health RI, exclusive breastfeeding is breastfeeding alone without any additional fluids or foods at 6 months of age.

Newborns are immediately given their first breast milk immediately with a maximum of 1 hour after birth. According Astuti $(2016,140)$ Breastfeeding may cause physical contact and the baby's suction will stimulate milk production especially in the first 30 minutes after birth [6]. Breastfeeding is very important and the beneficiary community agrees with this statement because breast milk can increase body resistance, nourish, improve child growth and development. Accompanied communities know the content of breast milk after giving the related material, the content contained in breast milk such as colostrum, antibodies, milk proteins, carbohydrates, fats. According to (Roesli, 2008) breast milk contains all the nutrients and fluids needed to meet all the nutritional infants in the first 6 months [7]. Breast milk serves as an antibody and the fulfillment of baby's nutritional intake, breast milk expended by a mother in the first 30 minutes after a new yellow, thick baby is a good nutrient for a baby called colostrum.

The frequency of breastfeeding babies should not be excessive. Of the questionnaire. It is known that the community of breastfed children breastfed 3-5 times. Incorrect frequency and duration of breastfeeding may affect the occurrence of breastfeeding problems. Problems associated with breastfeeding may adversely affect milk production such as scuffed nipples, swollen breasts, and breast milk dams [8]. According to Gartner (2005), breastfeeding every two-three hours will keep milk production high [9]. For women in general, breastfeeding or milking eight times in 24 hours will keep breastfeeding production high in early breastfeeding, especially the first four months. 
The benefits of extending exclusive breastfeeding and MPASI materials that meet balanced nutrition criteria are not only to add insight and as candidates for disseminating extension materials to other communities, but also to change attitudes as the impact of scientific literacy. Communities agree that infants should be exclusively breastfed and formula milk is not good enough to replace breast milk because its nutrients are no better when compared with exclusive breastfeeding. According Sulistiyowati $(2014,91)$, Mothers who choose to give exclusive breastfeeding is the right step. Many positive things can be felt by babies and mothers [10]. In addition, formula milk is more difficult to digest because it contains more casein. This is not in accordance with infant infantation that is still in the adjustment stage. Infants fed formula are highly susceptible to diseases such as gastrointestinal infections, respiratory infections, increased risk of allergies, increased risk of asthma attacks, decreased development of cognitive intelligence, increased risk of obesity, risk of heart disease and blood vessels, risk of diabetes mellitus, chronic disease risk [7].

Based on the data collected from the questionnaire given to the assisted community, it is expected that after the material extension has been submitted there is a change of behavior towards the better as a result of the learning process. In general, assisted communities have provided exclusive breastfeeding to their babies. However, partly because of busy work and lack of milk production so that mothers do not have time to give breast milk Breast milk production is less and slow out can cause the mother not to give milk to her baby with enough. In addition to the prolactin hormone, the lactation process also depends on the hormone oxytocin, which is released from the posterior pituitary as a reaction to suctioning of the nipple. Oxytocin affects the mioepithel cell that surrounds the mammary alveoli so that the alveoli contracts and secretes the milk already secreted by the Mammae glands, the oxytocin reflex is affected by the mother's soul. If there is anxiety, stress and doubt that occurs, then the expenditure of breast milk can be hampered.

Maternal health also plays a role in the production of breast milk. If the mother is not healthy, less food intake or lack of blood to bring nutrients to be processed by breast acini cells. This causes the production of breast milk to decline. According to Nilas and Michael Newton in Briefs Footnotes on Maternity Care, the success of breastfeeding relies heavily on mother's emotions and attitudes [11].

Parents who understand the importance of breastfeeding, continue to breast feed to their children by pumping breast milk and store it in a bottle closed when it will leave the baby. However, according to Roesli (2008) the recommended method of breast milk is to use the hands and fingers because it is practical, effective and efficient compared to using a pump [7]. Flushing with the hands and fingers has the advantage besides the negative pressure can be regulated, more practical and economical as it is enough to wash hands and fingers before squeezing the milk.

Based on the questionnaire filled by the respondents, information on the majority exclusive breastfeeding was obtained from the counseling. Thus, counseling about the importance of exclusive breastfeeding can be said to be successful and is expected to be a carrier information for others. In addition, the community gets information from doctors, health workers and families.

\section{CONCLUSION}

Accompanied communities are more aware of the importance of breastfeeding until the age of two and know the difference in formula milk with breast milk so that if the community is more likely to give breastfeeding to their babies compared with formula feeding.

Accompaniment community considers that the implementation of counseling is going well and according to their expectations, interesting and not saturated to be heard. The contestant is also able to master and can explain the extension material in great detail and can answer all questions asked by the participants.

\section{ACKNOWLEDGMENT}

We thank the Institute of Community Service Center UIN Sunan Gunung Djati Bandung who has funded this PKM and PKBM Wijayakusumah Bandung for cooperation so that this activity can successfully.

\section{REFERENCES}

[1] A.D. Sodioetama, Ilmu Gizi. Jakarta: PT. Dian Rakyat, 1985.

[2] M.B. Frost, et al. "Maternal Education and child nutritional Status in Bolivia : Finding the links, " Social Science \& medicine”, vol. 60, pp. 395-407, 2005.

[3] Gyaltsen, K., C. Gewa, H. Greenlee, J. Ravetz, M. Aikman, and A. Pebley. 2007. "Socioeconomic Status and Maternal and Child Health in Rural Tibetan Villages." On-Line Working Paper Series, California Center for Population Research, UC Los Angeles, http://escholarship.org/uc/item/04d8b3mv, accessed on June 23, 2012 Nutrition and Healthcare for Children from Rural Tibetan Households

[4] Mardiana, 2005, Hubungan Perilaku dengan Status Gizi Balita di Puskesmas Tanjung Bringin Kecamatan Hinai Kabupaten Langkat,Universitas Sumatera Utara, Skripsi

[5] Zuraida, R dan Julita N. 2010. Hubungan Antara Pengetahuan Dan Sikap Gizi Ibu Dengan Status Gizi Balita Di Wilayah Kerja Puskesmas Rajabasa Indah Kelurahan Rajabasa Raya Bandar Lampung. Fakultas Kedokteran Universitas Lampung .

[6] Astuti, Si, dkk. "Pengaruh Pelatihan Pemberian ASI Ekslusif terhadap Pengetahuan Menyusui Kelompok Pendukung ASI di Desa Mekargalih dan Cipacing Kecamatan Jatinangor Kabupaten Sumedang,” JSK, vol. 1, no. 3, 2016.

[7] Roesli, Panduan Inisiasi Menyusui Dini. Jakarta: Pustaka Bunda, 2008.

[8] R.N. Ardyan, Hubungan Frekuensi Dan Durasi Pemberian Asi Dengan Kejadian Bendungan Asi Pada Ibu Nifas.

[9] L.M. Gartner and A.I. Eidelman, Breastfeeding and the use of human milk. Pediatrics, 2005.

[10] T. Sulistiyowati and P. Siswantara, "Perilaku Ibu Bekerja Dalam Memberikan Asi Eksklusif Di Kelurahan Japanan Wilayah Kerja Puskesmas Kemlagimojokerto," Jurnal Promkes, vol. 2, no. 1, pp. 91. Surabaya: Universitas Airlangga, 2014.

[11] Notoatmodjo, Pendidikan dan Perilaku Kesehatan. Jakarta: Rineka Cipta, 2007. 